\title{
Involvement of the vomeronasal organ and prolactin in pheromonal induction of delayed implantation in mice
}

\author{
J. F. Bellringer, Hester P. M. Pratt and E. B. Keverne \\ Department of Anatomy, University of Cambridge, Cambridge CB2 3DY, U.K.
}

\begin{abstract}
Summary. Pregnancy block caused by exposure of mated female mice to a strange male was significantly reduced by bilateral destruction of the vomeronasal organ. Treatment of newly mated females with $\alpha$-bromocriptine also produced pregnancy block. Pregnancy block also occurred in mated females exposed to strange male odours, but the blastocysts which had failed to implant were still present in the uterus and were viable for up to 15 days after mating. Implantation was induced in such mice by administration of exogenous progesterone and oestradiol.
\end{abstract}

\section{Introduction}

A block to pregnancy by strange males was first described by Bruce (1959) who found that over $70 \%$ of impregnated female mice returned to oestrus after coming into contact with a strange male within $72 \mathrm{~h}$ of the initial mating. The block was shown to be determined by olfactory stimuli because ablation of the olfactory bulbs abolished the effect (Bruce \& Parrott, 1960) and mated females exposed only to soiled bedding from strange males also returned to oestrus (Parkes \& Bruce, 1962). The production of the pregnancy blocking pheromone is androgendependent because the block fails to occur with urine from castrated male mice (Bruce, 1965) and can be induced by urine from androgenized females (Dominic, 1966). The pheromone responsible has not yet been identified, but pregnancy block can be elicited by male urinary proteins (Marchlewska-Koj, 1977).

Although the action of the pregnancy blocking pheromone is prevented by removal of the olfactory bulbs, this procedure destroys both the main and accessory olfactory projections. One of these projections, originating in the vomeronasal organ, is involved in primer pheromone reception (Johns, Feder, Komisaruk \& Mayer, 1978; Keverne, 1979). While it seems probable that the vomeronasal organ might also contain the receptors for the pregnancy blocking pheromone, this has not yet been shown.

The immediate cause of pregnancy block is thought to be a failure of luteal function (Dominic, 1970; Milligan, 1976a) and the reason for this luteal failure has been suggested to be either an increased secretion of gonadotrophins (Hoppe \& Whitten, 1972) or a suppression of prolactin (Bruce \& Parkes, 1960; Milligan, 1976b). Unfortunately the evidence in support of either of these proposals is largely circumstantial. The failure of luteal function produced by the pregnancy blocking pheromone is in turn thought to be responsible for the failure of implantation (Bruce \& Parkes, 1961a; Dominic, 1970). In mice (Bruce, 1960) or voles (Milligan, 1976a) there were no obvious signs of embryos following the olfactory block to pregnancy, and their fate was not determined.

The purpose of this present study was to assess the importance of the vomeronasal organ in the olfactory block to pregnancy, and the possible neuroendocrine mechanism of action of mouse primer pheromones. By flushing the oviducts and uteri of mice in which the pregnancy block was achieved, it was further hoped to establish the fate and status of embryos. 


\section{Materials and Methods}

Adult female CFLP mice weighing around $25 \mathrm{~g}$ were housed in pairs or singly in plastic cages with wood shaving as bedding. The lighting (12 h light $(06: 00-18: 00 \mathrm{~h}) / 24 \mathrm{~h})$ and temperature $\left(20 \pm 1^{\circ} \mathrm{C}\right)$ were controlled. Mice were allowed to ovulate naturally or induced to superovulate by i.p. injections of 5 i.u. PMSG (Folligon: Intervet, Cambridge CB2 8EW) followed by 5 i.u. hCG (Chorulon: Intervet) 44-48 h later. These females were mated with CFLP males. Mating was confirmed by the presence of a vaginal plug the following morning which was designated Day 1 of pregnancy. Adult males of a hybrid strain, $F_{1} L A C(C B A \times C 57 \mathrm{BL})$, were used to provide soiled bedding or to block pregnancy directly.

Vaginal smears were taken daily between 15:00 and 17:00 h, and oestrus was identified by a smear containing mainly enucleated cornified cells. Pregnancy was considered to be blocked if an oestrous vaginal smear was seen within 7 days of mating, in accordance with the original experiments of Bruce (1960). The data were subjected to a $\chi^{2}$ test for significance of changes (Siegel, 1956).

For excision of the vomeronasal organ, the mice were injected with tribromoethanol (Avertin: $0.02 \mathrm{ml} / \mathrm{g}$ body wt) and placed supine in an adapted small-animals stereotaxic holder. The lower jaw was retracted and small, bilateral incisions (about $1 \mathrm{~mm}$ long) were made in the palate of the upper jaw 3-4 mm posterior to the upper teeth. This exposed bilaterally the paramedial Jacobson's cartilages enclosing the vomeronasal epithelium. Using a diathermic cutting tool, the entire organ on each side was cut and burnt away. The resulting gap in the upper palate was filled with polycyanoacrylate tissue cement (Simplex: Howmedica International, London NI6 0BP) and the animals were allowed to recover under observation in a warm place. Histological examination of sagittal head sections at autopsy was used to confirm that the vomeronasal organ had been completely destroyed. Sham operations included the anaesthesia, incisions and diathermic cutting of the lower jaw in the midline.

\section{Experiment 1}

Mice were allocated to 3 groups: there were 16 intact females in Group A, 16 from which the vomeronasal organs had been removed in Group B and 10 sham-operated females in Group C. For all groups, pairs of females were placed in a cage with an $F_{1}$ male at 10:30 h on Day 2 after finding a vaginal plug. The females were removed at 10:30 h on Day 4 and returned to their own cages. Vaginal smears were taken daily on Days 2-8 inclusive.

\section{Experiment 2}

Eleven (11) female mice were induced to superovulate by i.p. injection of 5 i.u. PMSG (Folligon: Intervet) followed by $5 \mathrm{i} . \mathrm{u}$. hCG (Chorulon: Intervet) $44-48 \mathrm{~h}$ later. The females were left with a CFLP male overnight and mating was confirmed by the presence of a vaginal plug (Day 1). At 10:30 h on Day 2 a single i.p. injection of $5 \mathrm{mg}$ bromocriptine (CB 154: Sandoz $\mathrm{Ltd}) / \mathrm{kg}$ was given. This drug acts as dopamine agonist, and a single injection is effective in lowering prolactin levels (Carr, Conway \& Voogt, 1974). Superovulation and mating were induced similarly in 9 mice but the control injection consisted only of the vehicle (tartaric acid and alcohol, diluted with $0 \cdot 154 \mathrm{M}-\mathrm{NaCl}$ ). Vaginal smears were taken on Days 2-8 inclusive.

\section{Experiment 3}

To investigate the fate of embryos in which pregnancy had been blocked 15 mice (Group A) were induced to superovulate and mated with CFLP males. These females were caged singly or in pairs and at 10:30 h on Day 2 soiled bedding from a cage containing $F_{1}$ males was added to 
these cages and more soiled bedding was added at 12-h intervals up to Day 4 . Bedding was used to eliminate any possibility of embryos being derived from matings with the alien male. Vaginal smears were taken on Days 1-7 inclusive. The animals were killed by cervical dislocation on Day 9, the condition of the ovaries and uterus was noted and the oviducts and uteri were removed and flushed with sterile phosphate-buffered saline. When embryos were found these were transferred to RPMI medium $+10 \%$ fetal calf serum and incubated at $37^{\circ} \mathrm{C}$ in $5 \% \mathrm{CO}_{2}$ in air, under paraffin oil, to observe development.

A further 14 mice (Group B) were similarly induced to superovulate and mate and then exposed to soiled bedding. Vaginal smears were taken on Days 1-7 inclusive. Five (5) of the mice were given a subcutaneous injection of $1 \mathrm{mg}$ progesterone in arachis oil on Days 9 and 10 followed by $50 \mathrm{ng}$ oestrogen $+1 \mathrm{mg}$ progesterone on Days 11 and 12 and then $1 \mathrm{mg}$ progesterone on Days 13 and 14. The control group of 5 mice received equivalent volumes of arachis oil daily from Day 9, and all 10 mice were killed on Day 15. Ovaries, oviducts and uteri were inspected and embryos cultured as before. The remaining 4 mice were killed on Day 23 and examined for embryos.

To demonstrate that the diapausing embryos were capable of implanting in vivo, 5 mice (Group C) which had been mated and exposed to male bedding were injected (starting on Day 9) with doses of progesterone and oestrogen sufficient to induce implantation in pregnant ovariectomized mice (Pratt, 1977). The mice were examined on Day 19.

\section{Results}

As shown in Table 1, there was a significant decrease in pregnancy block in Group B mice compared with that in Groups $A$ and $C$ in Exp. 1. Sham operations had no significant effect on the ability of females to respond to pregnancy block.

In Exp. 2 a significantly higher proportion of mice treated with bromocriptine showed pregnancy block (Table 1).

Table 1. Effects of vomeronasal lesions, $\alpha$-bromocriptine or exposure to soiled bedding on pregnancy block in mice

\begin{tabular}{|c|c|c|c|c|c|c|}
\hline \multirow[b]{2}{*}{ Exp. } & \multirow[b]{2}{*}{ Group } & \multirow[b]{2}{*}{ Treatment } & \multicolumn{2}{|c|}{ No. of females } & \multirow[b]{2}{*}{$\begin{array}{l}\% \text { blocked } \\
\text { pregnancies }\end{array}$} & \multirow[b]{2}{*}{ Significance } \\
\hline & & & Tested & $\begin{array}{l}\text { Returning to } \\
\text { oestrus }\end{array}$ & & \\
\hline \multirow[t]{3}{*}{1} & A & Housed with strange male & 16 & 13 & $82\}$ & \multirow{3}{*}{$\left.\begin{array}{l}P<0.001 \\
P<0.01\end{array}\right\} N$} \\
\hline & B & $\begin{array}{l}\text { Excision of vomeronasal organ and } \\
\text { housed with strange male }\end{array}$ & 16 & 4 & 20 & \\
\hline & $\mathrm{C}$ & $\begin{array}{l}\text { Sham operation and housed with } \\
\text { strange male }\end{array}$ & 9 & 7 & $78\}$ & \\
\hline 2 & & $\begin{array}{l}\text { Mated and vehicle injected } \\
\text { Mated + bromocriptine }\end{array}$ & $\begin{array}{r}9 \\
11\end{array}$ & $\begin{array}{l}0 \\
7\end{array}$ & $\left.\begin{array}{r}0 \\
64\end{array}\right\}$ & \multirow[t]{2}{*}{$P<0.005$} \\
\hline 3 & & $\begin{array}{l}\text { Mated and exposed to bedding } \\
\text { from strange male }\end{array}$ & 15 & 6 & 40 & \\
\hline
\end{tabular}

In Exp. 3, only 6 of the 15 mice in Group A returned to oestrus as assessed by vaginal smears. When killed on Day 9, 1 of these 6 mice had an oestrous, fluid-filled uterus which contained no embryos, and a second contained 20 Day -9 implantation sites. The other 4 mice all had diapausing embryos (3-11/mouse) in their uteri. Amongst the 9 mice which did not show a return to oestrus, one had an oestrous uterus which did not contain any embryos but the other 8 mice all contained diapausing embryos (5-27/mouse). A total of 129 diapausing embryos was obtained from this experiment. Large corpora lutea were found in the ovaries of all mice which contained diapausing embryos and the uteri had a progestational appearance. Diapausing 
embryos were also recovered from the Group B mice killed on Day 15. However, the uterine horns were very slender and underdeveloped, similar to those of an ovariectomized mouse and there were no obvious recent corpora lutea. No embryos were recovered from the 4 mice killed on Day 23 and all had resumed oestrous cycles as indicated by the state of the uteri and ovaries. Of the control group injected with arachis oil alone, 3 out of 5 mice had uteri which contained diapausing embryos and were similar in appearance to uteri of ovariectomized mice, while the remaining 2 mice had oestrous uteri which did not contain any embryos.

Of the diapausing embryos collected, 70 were cultured in vitro and embryos from every animal examined were included. Within $24 \mathrm{~h}$, all embryos had expanded and attached. Trophectoderm outgrowths with attached clusters of inner cell mass cells developed and continued to do so for more than 7 days in culture; $10-15 \%$ developed to early egg cylinder stages.

In Group C, 3 of the 5 mice had 2-day-old implantation sites in their uteri $(4,5$ and 6 sites respectively) while the remaining 2 mice had 6-10 diapausing embryos remaining unimplanted in their uteri.

\section{Discussion}

These experiments demonstrate that complete lesions of the vomeronasal organ prevent the olfactory block to pregnancy (Bruce effect). The inability of such females to respond to the odour of alien males is strong evidence for the presence of receptors for this pheromone in the vomeronasal organ. Receptors for pheromonally mediated suppression of oestrus in mice are also known to be present in the vomeronasal organ (Reynolds \& Keverne, 1979). Because of the close anatomical relationship between the vomeronasal organ and the hypothalamus (Scalia \& Winans, 1975), such pheromones probably exert their effects via the hypothalamic-pituitary axis, perhaps by an increased secretion of gonadotrophins (Chapman, Desjardins \& Whitten, 1970; Hoppe \& Whitten, 1972; Bloch, 1973). Moreover, Bronson (1976a, b) has also shown that male pheromones do increase LH levels in grouped ovariectomized female mice. An increase in LH should not, however, lead to the regression of the corpus luteum which has been observed in pregnancy block (Dominic, 1966). The evidence that prolactin is the hormone mainly responsible for pregnancy block arose from the early experiments of Bruce \& Parkes (1960, $1961 \mathrm{~b}$ ) in which suckling or injection of exogenous prolactin protected mice from the pregnancy block. This has more recently been proposed as the immediate cause of pregnancy block in the vole (Milligan, 1976a; Charlton, Milligan \& Versi, 1978). Further evidence is provided by the present study in which the dopamine agonist $\alpha$-bromocriptine also succeeded in blocking pregnancy. The effect of the drug, although significant, was not quite as great as that of an alien male, but since bromocriptine's action in lowering prolactin is effective over hours rather than days (Sinha, Salcocks \& Vanderlaan, 1975) the number of animals blocked could probably be increased by continued treatment. Exposure to urine for 2 days is similarly more effective in increasing the number of females which show pregnancy block when compared with exposure for only $12 \mathrm{~h}$ (Bruce, 1961).

The discovery of diapausing embryos in mice which had passed through oestrus according to vaginal smear data (4 out of 6) was unexpected. In previous work (Bruce, 1959, 1960) embryos from the initial mating were never found and hence were assumed to have been lost during the ensuing oestrus. However, we have been unable to recover any embryos from oestrous uteri, even though the vaginal smear data clearly indicate that some mice carrying diapausing embryos have been in oestrus. Whether an oestrous vaginal smear is indicative of the typical fluid-filled uterus in this situation still remains to be determined. Diapausing embryos were also found in 8 out of 9 animals which did not show vaginal oestrous smears and hence would be classified as not showing pregnancy block. This group may correspond to the mice 
described as pseudopregnant in Bruce's original studies (Bruce, 1960). Diapausing embryos were recovered from both types of animal up until approximately Day 15 but were no longer obtained by Day 23. These embryos were clearly viable as demonstrated by their ability to outgrow in vitro and implant in vivo following appropriate hormone stimulation to the mother.

The presence of diapausing embryos was restricted to those animals exposed to the male odour alone. The mice that had been exposed to the alien males themselves during early pregnancy showed no signs of the original set of embryos as previously observed (Bruce, 1960).

There are two possible reasons why this phenomenon of pheromone-induced diapause has not been described before. Firstly, diapausing mouse blastocysts are difficult to identify since they settle into the uterine crypts and become compressed laterally to such a extent that the blastocoele is completely obliterated and they can be easily overlooked and discarded as fragments of uterine epithelium. However, after a few hours in culture they expand and form the characteristic morphology of a hatched blastocyst. Secondly, it is not clear from the previous study (Bruce, 1960) whether the different ways of blocking pregnancy were taken into account when the fate of the embryos was examined. For example, animals that were exposed to male odour alone may not have been explicitly distinguished from those exposed to males themselves.

We are at present unable to define with certainty the conditions which lead to a high incidence of diapause among females exposed to male odour early in pregnancy. Factors which may predispose to diapause, age and condition of the male, age of the female, previous exposure to males, and parity, are now being investigated. Nevertheless, it seems clear that a block to implantation resulting in embryonic diapause can occur in response to odour cues alone, whereas the additional auditory, visual and/or tactile stimuli from the male itself result in loss of the embryos.

Thus there is clearly a range of possible reactions to pheromonal stimulation ranging from failure to implant and a return to oestrus, through failure to implant and suppressed oestrus, to complete loss of embryos when the odour cue is accompanied by other sensory information.

We acknowledge support from the M.R.C. (H.P.) and Department of Anatomy (J.B.); and thank Caroline Hunt for typing the manuscript.

\section{References}

Bloch, S. (1973) Nidation induced in mice during the lactational delay by the presence of strange males. $J$. Endocr. 57, 185-186.

Bronson, F.H. (1976a) Urine marking in mice: causes and effects. In Mammalian Olfaction, Reproductive Processes and Behavior, pp. 119-141. Ed. R. L. Doty. Academic Press, New York.

Bronson, F.H. (1976b) Serum FSH, LH and prolactin in adult ovariectomised mice bearing silastic implants of estradiol: responses to social cues. Biol. Reprod. 15, $147-152$.

Bruce, H.M. (1959) An exteroceptive block to pregnancy in the mouse. Nature, Lond. 184, 105.

Bruce, H.M. (1960) A block to pregnancy in the mouse caused by proximity of strange males. J. Reprod. Fert. 1, 96-103.

Bruce, H.M. (1961) Time relations in the pregnancy block induced in mice by strange males. J. Reprod. Fert. 2, 134-142.

Bruce, H.M. (1965) Effect of castration on the reproductive pheromones of male mice. J. Reprod. Fert. 10, 141-143.
Bruce, H.M. \& Parkes, A.S. (1960) Hormonal factors in exteroceptive block to pregnancy in mice. $J$. Endocr. 20, 29-30.

Bruce, H.M. \& Parkes, A.S. (1961a) An olfactory block to implantation in mice. J. Reprod. Fert. 2, 195-196.

Bruce, H.M. \& Parkes, A.S. (1961b) The effect of concurrent lactation on the olfactory block to pregnancy in the mouse. J. Endocr. 22, 6-7.

Bruce, H.M. \& Parrott, D.M.V. (1960) Role of the olfactory sense in pregnancy block by strange males. Science, N.Y. 131, 1526.

Carr, L.A., Conway, P.M. \& Voogt, J.L. (1974) Inhibition of brain catecholamine synthesis and release of prolactin and $\mathrm{LH}$ in the ovariectomised rat. J. Pharmac. Exp. Ther. 192, 15-21.

Charlton, H.M., Milligan, S.R. \& Versi, E. (1978) Studies on the control of the corpus luteum in the vole, Microtus agrestis. J. Reprod. Fert. 52, 283288.

Chapman, V.M., Desjardins, C. \& Whitten, W.K. (1970) Pregnancy block in mice: changes in pituitary $\mathrm{LH}$ and LTH and plasma progesterone levels. J. Reprod. Fert. 21, 333-337. 
Dominic, C.J. (1966) Observations on the reproductive pheromones of mice. II. Neuroendocrine mechanisms involved in the olfactory block to pregnancy. $J$. Reprod. Fert. 11, 415-421.

Dominic, C.J. (1970) Histological evidence for the failure of corpus luteum function in the olfactory block to pregnancy. J. Anim. Morph. Physiol. 17, 126-130.

Hoppe, P.C. \& Whitten, W.K. (1972) Pregnancy block: imitation by administered gonadotrophin. Biol. Reprod. 7, 254-259.

Johns, M.A., Feder, H.H., Komisaruk, B.R. \& Mayer, A.D. (1978) Urine induces reflex ovulation in anovulatory rats: a vomeronasal effect. Nature, Lond. 272, 446-448.

Keverne, E.B. (1979) The dual olfactory projections and their significance for behaviour. In Chemical Ecology: Odour Communication in Animals, pp. 75-85. Ed. F. J. Ritter. Elsevier, Amsterdam.

Marchlewska-Koj, A.C. (1977) Pregnancy block elicited by urinary proteins of male mice. Biol. Reprod. 17, $729-732$.

Milligan, S.R. (1976a) Pregnancy blocking in the vole, Microtus agrestis. I. Effect of the social environment. J. Reprod. Fert. 46, 91-95.
Milligan, S.R. (1976b) Pregnancy blocking in the vole, Microtus agrestis. II. Ovarian, uterine and vaginal changes. J. Reprod. Fert. 44, 97-100.

Parkes, A.S. \& Bruce, H.M. (1962) Pregnancy block in female mice placed in boxes soiled by males. $J$. Reprod. Fert. 4, 303-308.

Pratt, H.P.M. (1977) Uterine proteins and the activation of embryos from mice during delayed implantation. J. Reprod. Fert. 50 1-8.

Reynolds, J.M. \& Keverne, E.B. (1979) The accessory olfactory system and its role in pheromonally mediated suppression of oestrus. J. Reprod. Fert. 57, 31-35.

Scalia, F. \& Winans, S.S. (1975) The differential projection of the olfactory bulb and accessory olfactory bulb in mammals. J. comp. Neurol. 161, 31-56.

Siegel, S. (1956) Non-parametric Statistics for the Behavioral Sciences. McGraw-Hill, New York.

Sinha, Y.N., Salcocks, C.B. \& Vanderlaan, W.P. (1975) A comparison of the effects of CB 154 and lergotrile mesylate on prolactin and growth hormone secretion in mice. Horm. Metab. Res. 8, 322-336.

Received 8 November 1979 